\title{
Participation and responsibility
}

DOI: http:/ /dx.doi.org/10.1590/abd1806-4841.201994101

The Brazilian Society of Dermatology (SBD) has a long history of struggle for the Brazilian people's health and wellbeing, always focusing on activities that benefit and reach the population as a whole. The National Skin Cancer Awareness Campaign is an outstanding example. The first campaign for skin cancer prevention was conceived and launched in 1987 by Jarbas Porto, a dermatologist and professor at the State University of Rio de Janeiro. In the following decade, under the chairmanship of Professor Alberto Cardoso, the campaign was officially expanded by the Society to reach all of Brazil. The National Campaign for the Prevention of Skin Cancer (CNPCP) is part of the National Program for the Control of Skin Cancer (PNCCP) conducted by SBD since 1999. In the year 2018, the Society is thus celebrating the $20^{\text {th }}$ edition of this nationwide campaign.

The movement "Orange December", conceived in 2014 under the administration of Professor Denise Steiner, was made official in the sense of further reinforcing the population's awareness as Brazil approaches summer and the start of school vacation. SBD has worked tirelessly for a campaign that receives wide media support, with the aim of obtaining maximum visibility and nationwide impact in relation to skin cancer, its primary preventive measures, and the importance of early diagnosis.

Starting this year, the campaign features a slogan that was conceived after a detailed survey on sun-loving Brazilians' behavior: "Enjoy the sun, but don't get burned!". The Society is aware that the sun is part of daily life in Brazil, but that we have the obligation as dermatologists to caution people on the measures they should take in relation to solar exposure. The campaign thus provides relevant information through dialogue and mass publicity on this subject in all of its communications channels (social networks, the SBD website, bulletins, and e-news), besides the mainstream print and broadcasting media.
From December through the end of summer (late March in Brazil), we will be holding numerous activities, the most important of which is the National Day for Free Skin Cancer Tests. On the first Saturday of December, four thousand dermatologists and volunteers will provide free testing in more than 130 health services all across Brazil. Last year the campaign resulted in 26,161 tests, and 3,852 cases of skin cancer were identified, including basal cell carcinoma (2,765), squamous cell carcinoma (724), and melanoma (363).

We recently received highly encouraging news that urges us to continue with our public awareness-raising approach. As of this year, the SBD will enjoy the support of the American Academy of Dermatology (AAD) and the International League of Dermatology Societies (ILDS) in our awareness-raising activities to reduce cases of skin cancer in Brazil. All the materials produced by the SBD will thus include the seal of the World Skin Health Day (WSHD) of ILDS and the identifier "@AADSkin" and "\#AAD".

As an example of the magnitude of our campaigns, on December 5, 2009, the SBD was certified by the Guinness World Book of Records for having held the world's largest medical campaign on a single day, the largest skin cancer prevention campaign in the world, having tested more than 34 thousand Brazilians in different regions of the country. This milestone further highlights the legitimacy and international recognition of our National Skin Cancer Awareness Campaign.

On behalf of the Brazilian Society of Dermatology, I wish to take advantage of the opportunity to thank the Brazilian dermatologists and other collaborators for their commitment in developing these projects that are now a national reality, and with recognition by the international dermatology community. In more than 20 years, we have consolidated this collaboration in the search for better skin health for Brazil's population. And this has been a permanent pursuit during our administration in the last two years. $\square$

José Antonio Sanches Jr.

Department of Dermatology, University of Sao Paulo, Brazil.

President of Brazilian Society of Dermatology 2017-2018

José Antonio Sanches Jr

(iD) ORCID

0000-0002-5709-092X

(c) BY-NC 